\title{
MOVING BEYOND MARKET FUNDAMENTALISM TO A MORE BALANCED ECONOMY*
}

\author{
by \\ D. Joseph STIGLITZ \\ Nobel Prize in Economics, University of Columbia (EEUU)
}

It is a real pleasure to be here to talk about a subject which has received increasing attention in the last week. In some ways, just as the fall of the Berlin Wall marked the end of Communism, 15 September 2008, marked the end of market fundamentalism, even though the weaknesses in both systems were evident long before. It was on 15 September that the American government made clear that it did not believe that markets by themselves worked and that for the American economy to continue, it would take massive governmental interventions of an unprecedented scale, larger in many ways than had even occurred during the Great Depression. Prior to that date, the US government had already spent 900 billion dollars, almost a trillion dollars, in bail-outs. It had increased the national debt by over five trillion dollars by assuming the debts of Fannie Mae and Freddie Mac. These are such large numbers that it is hard to come to terms with them, but they are the magnitude of what has happened in the last couple of weeks. But then, the US government made a commitment that it would take on literally hundreds of billions of dollars of bad mortgages; most experts think that it will probably be closer to another trillion dollars.

Thus, we have a massive rethinking of the role of the government and of the market. What I want to do is to look at this from a broader, more historical perspective and to end with some

\footnotetext{
* This paper was presented in opening session of the $27^{\text {th }}$ international congress of CIRIEC, Sevilla 22-24 September, 2008

Email: jb2632@columbia.edu 
comments about the role of the social economy as we move towards the construction of a more balanced economy.

\section{$1 \quad$ Market fundamentalism}

From a historical point of view, for a quarter of century the prevailing religion of the West has been market fundamentalism. I say it is a religion because it was not based on economic science or historical evidence. It was sold by Thatcher in the UK and by Reagan in the USA. It made reference to some old ideas in economics, specifically to Adam Smith's notion of the invisible hand, which is the argument that firms who pursue their self-interest and the maximization of profits would lead, as if by an invisible hand, to general societal well-being. I will return to that argument momentarily because, while that is a widely held assumption, Adam Smith himself was very aware of the limitations of this argument. In fact, he warned very explicitly of the dangers of unfettered markets; but those who advocated this kind of market fundamentalism advocated a particular form of economic organization: profit-maximizing firms without government regulation.

In a way, this particular set of ideas came under severe criticism 75 years ago. The Great Depression showed that markets do not necessarily work well. How could one think markets worked well, when in Europe and the USA, one out of four people were involuntarily out of a job? It was also clear that economies do not necessarily self-correct or self-regulate, at least in the relevant time frame. Some people said that the markets will eventually adjust, in the long run, and Keynes' response to that was, 'Yes, but in the long run we are all dead'. Keynesian economics, in a way, rescued the market. Had it not been for the notion that Keynes put forward, that with appropriate governmental intervention we could maintain the economy at full employment, support for market-based economics may have eroded very quickly. The irony is that Keynes, viewed widely as a critic of market economics, actually turned out to be its savior.

Thus, it has come to widely be accepted, both on the left and on the right, that government macro-interventions are necessary to sustain the economy. Even conservatives like President Bush in the USA have argued for the necessity of the use of stimulus packages to keep the economy going. To be sure, there are a few places in the world where these ideas are not universally accepted. In the East 
Asia crisis, a decade ago, the IMF resorted to pre-Keynesian ideas that advocate responding to the crisis by raising taxes and lowering expenditures. But we all know what happened to these economies as a result of these IMF policies: the downturns turned into recessions and recessions into depressions. This provided further evidence of the validity of Keynesian propositions, that when there is an economic downturn there is a need for strong government intervention and expansionary monetary and fiscal policies.

In the aftermath of Keynesian economics, a particular set of ideas were developed, called the neo-classical synthesis. This was the idea that, once the economy was restored to full employment, market forces could once again be relied upon to allocate resources. In a sense, what it said is: 'Yes, you need government to maintain macro stability, but if the government did its job then you can rely on markets for micro economic efficiency'. Now, the interesting thing about the neo-classical synthesis was that it was not based on any economic theory. It was put forward as an assertion, actually by my teacher Paul Samuelson, and was widely accepted around the world. However, as I argued many years ago, it was far more plausible that macro-economic problems are the tip of the iceberg of much more pervasive market failures: markets often don't work very well. These macro economic failures are so large that no one could ignore them.

\section{Information economics}

When there is an economy with one out of four people unemployed, it is obvious that the economy isn't working well. But how do you know when the markets are allocating resources efficiently? How do you know when they are allocating capital, for instance, to the areas where the returns are highest? That was a difficult question. There were some answers we could understand; for instance, we knew markets didn't work well in the context of pollution or innovation as they produced too much pollution and too little innovation. Still, with these fairly well-defined exceptions, there was a widespread view that markets worked well, once the government maintained full employment. But that particular perspective was very strongly undermined by my work and the work of others on the new paradigm of the economics of information, which recognized that market participants, often or always, have imperfect information. There are large asymmetries of information; that is to say, some 
people know more than others. Conventional economics had been based on the hypotheses of perfect markets, perfect information, and perfect competition. The hope (and it was just that, a hope) that a world in which there were not too many imperfections would look approximately similar to a world in which all the imperfections of markets and information prevailed.

What my work showed, and the work, as I say, of others in this new field, was that that hope was wrong. Even small imperfections of information could have dramatic effects on outcomes, such as inefficient equilibria or monopoly pricing; in other words, the standard neo-classical model on which so much of modern policy is based was not robust, and Adam Smith was dramatically wrong. To put it another way, my work, and that of my colleague Bruce Greenwald at Columbia University, showed that whenever information was imperfect, which is always, the reason that the invisible hand so often seemed invisible was that, in fact, it was not there. The implication was that there were always government interventions that could make everyone in society better off, which was, in a sense, a theoretical repeal of market fundamentalism: the belief that markets worked on their own and acted with efficiency was simply not true. It is ironic that just as I was proving these results, the notion of market fundamentalism became increasingly widespread. My own work was done in the early seventies, but it was not until the eighties that Thatcher and Reagan started propagating the ideas of market fundamentalism, which became widely accepted, just as economic theory was strongly rejecting these notions.

\section{Historical experience}

My research showed that one needed to find a balance between markets, government, and other institutions, including not-for-profits and cooperatives, and that the successful countries were those that had found that balance. In short, market fundamentalism, sometimes referred to as neo-liberalism, was simply wrong. There were a wide variety of historical experiences which confirmed this perspective. We can look at it from both the successes and the failures. The last 50 years have actually been very dramatic. We have seen successes in development beyond anything that we could have imagined, but we have also seen dramatic failures. The countries that followed the neo-liberal policies, which focused on market fundamentalism and the idea that markets worked on their own, by and large failed. 
These were doctrines that were especially widespread within Latin America.

On the other hand, the region of the world that was most successful was East Asia. One of the exciting research projects that I worked on in the late eighties/early nineties was called the East Asia Miracle, where I tried to study what were the factors that had contributed to the success of this region. It wasn't just one country, it wasn't just Japan; it was country after country within the region. They shared a broad economic philosophy based upon a much greater array of institutional arrangements, with a large role played by government. An example of the array of institutions includes the township and village enterprises and cooperatives in China, which played a critical role in that country's development in the nineties. Success in East Asia was clearly related to their not following the Washington Consensus and instead following a much more balanced course.

\section{The role of government}

The same is actually true if you look in more detail at the USA and Europe. The success of the USA was largely based on the government assuming a very important role, and if you look sector by sector you see that role. It had an important role in education, and actually, until recently, in finance. Before deregulation, the US government had a very important role in the regulation which helped create our national banking system. In fact, it was remarkable that in the midst of our great Civil War in 1863, Abraham Lincoln pushed through the first banking regulation act. And why did he do it? Because he saw that after the war we would need a national banking system, and for it to be successful, it would have to be well regulated. Lincoln put forward what those regulations were.

The government has also played an important role in providing finance: it created the modern mortgage but then made the mistake, partly to help finance the Vietnam War, of privatizing the mortgage companies. We are now facing the consequences of that flawed decision. It provided finance for small and medium-size enterprises through our Small Business Administration, and this too has been an enormous success in creating new industries. For instance, Federal Express, which began the overnight mail delivery system, was financed originally by a small business loan: a small business that has grown into a very big business. 
The government's role has been particularly important in technology and science. In the 19th century, the core of the American economy was agriculture. Research financed by the US government and extension services to bring the fruits of that research to ordinary farmers were the basis of the success of the American economy. The increased productivity provided the resources with which we were able to transition into manufacturing. The most important innovation of the last 25 years has been the Internet, which was financed by government. The role of government in telecommunications actually goes much longer back, to the early 19th century, when the first telegraph line was also financed by the US government. The other important innovation sector today is biotech, again based on research financed by the government. Finally, we cannot imagine a modern economy without infrastructure, without roads, without airports, which are again areas in which the government plays an important role.

\section{The role of cooperatives}

With these remarks, I want to remind us that in the midst of the view of so many (especially on the right) that the market does everything, the fact is that if you look at the success of the USA, it is largely based on the government playing an absolutely critical role. The government wasn't the problem; the government was the solution.

It is also the case that there are important roles for cooperatives. Historically, they played an important role in finance and insurance, and some of the problems we face today are a result of the conversion of those cooperatives into profit-maximizing enterprises. But, even today, in agriculture, housing, and other areas, cooperatives and non-profits play an important role. In fact, I feel very sensitive to that issue because my own life is surrounded by these institutions: I work for Columbia University, which is a not-for-profit and the most successful university in the USA (there is not a single major forprofit university in the USA), I live in cooperative housing, and my publisher, WW Norton, is one of the most successful publishers and is a cooperative.

I want to switch, for a moment, to talk a little bit about the new perspectives that the understanding of the balance between the role of the government and the role of the market brings out. There are three elements that I want to stress. First, one of the flaws of market 
fundamentalism is that it paid no attention to distribution of incomes or the notion of a good or fair society. But, in fact, as we looked at what has been associated with strong growth, a fair society with a better distribution of income can have more sustainable growth, in a social, political, and environmental sense. The reason for this is that people are a country's most important assets, and it is important to make sure that every person can perform up to their potential. Excessive inequality can give rise to macro-economic problems. I would argue that some of the problems that the USA is now facing are a result of its unbridled inequality, which has increased in recent years to levels not seen for almost a century.

Finally, the current debacle on the financial market brings home the fact that there is an important role for government in making markets work. Markets cannot work by themselves. There is a need, for instance, for bank regulation. It is easy for institutions like banks to take people's money, but the problem is if you get your money back. It is only in a situation where you have good regulation, when people can have the confidence that they will get their money back, that they're willing to turn over their money.

This is true in many other areas. One of the origins of food safety regulations in the USA was at the beginning of the last century. Upton Sinclair wrote a very influential book called The Jungle, in which he depicted American stockyards, where they slaughter cattle, so vividly that no one wanted to eat any meat. The response of the meat packing industry was to approach the government and say: 'Please, regulate us so that people will have confidence once again that our meat is safe to eat'. So, government, in effect, saved that industry. Today, in a way, we are in the same situation with respect to finance. The financial markets have mismanaged themselves, and they are so risky that people have lost confidence. That is what has happened in September 2008: the lack of confidence in financial markets led to the pull-out of money, so that even what had been viewed to be strong corporations could simply not get finance, and the government had to come in to provide reassurance.

\section{Facing a massive microeconomic failure}

In a sense, America is now facing a massive micro-economic failure on par with the macro-economic failure of the Great Depression. These problems were predictable and predicted. I don't 
want to say 'I told you so', but I did tell you so. In fact, economists are generally not very good about predicting the exact time when things will fall apart. We're not good at timing - if we were, we would be rich - but we are good at identifying the fundamental underlying forces. It was clear that our financial markets weren't working or doing what they were supposed to do. Financial markets are supposed to allocate capital and manage risk. They didn't allocate capital well, and they allocated hundreds of billions of dollars to mortgages beyond people's ability to pay. They didn't manage risk; they created risk. When they innovated, they weren't creating innovations that made our economy more efficient or more productive. All of this was in part the result of the lack of adequate regulation, the belief in market fundamentalism by the Fed and the Bush administration.

One of the ironies and one of the points that has been brought home very fiercely by these recent events is that we did have some regulations, but President Reagan had appointed Alan Greenspan, who did not believe in regulation, as Chairman of the Federal Reserve Board. If you go back to the mid 1980s, the USA had a very good central banker, Paul Volker. He managed to bring down inflation, and you would have thought, given that impressive record, that he would have been reappointed. Instead, he was fired by President Reagan because he understood that there was a role for government in the Fed and for regulation, and Reagan wanted somebody who did not believe in regulation. He found that person in Greenspan, and we are now experiencing the consequences of appointing someone who did not believe in regulation in the modern economy.

The financial firms were maximizing their profits and pursuing their greed in the short run. More accurately, the CEOs and other managers were maximizing their bonuses and income, but this didn't lead to the general welfare of our society. Once again, we have seen a dramatic illustration of the failure of Smiths' invisible hand. The pursuit of self interest, profit, old-fashioned greed, did not lead to societal well-being. Let me make it clear: this is not the first time that this has happened. In the USA this is the third or fourth time within the last 20 years. We had the S\&L debacle in 1989 and the WorldCom/Enron debacle at the beginning of this decade. In the late 1990s we misallocated hundreds of billions of dollars to fibre optics. At one point, $97 \%$ of all the fibre optics had seen no light. Our financial markets have misallocated capital and consistently mismanaged risk. 


\section{Gap between private rewards and social returns}

What has also been consistent has been the misalignment of private rewards and social returns: while they were messing up our economy, mismanaging risk and misallocating capital, they garnered for themselves, in recent years, over a third of all corporate profits. Now, you might have said: 'If they were getting all those corporate profits and, as a result of that, made our economy more efficient, then that's the price we pay for economic efficiency'. The irony is we have paid this huge price, but they have mismanaged our economy.

That leads to deeper questions of 'What went wrong?' When President Bush was asked what went wrong his answer was: 'We built too many houses'. While that was true, it wasn't exactly a deep analysis. One of the factors contributing to the problem was the lack of alignment of private rewards and social returns, and that's partly related to the incentive systems, which was based on stock options designed to obfuscate costs. They were designed to make everybody feel like you could give your CEO something that didn't cost anybody anything; you could just print the stock option. The reality is there is something called the conservation of matter: if you give the CEO something, it comes out of somebody else's pocket. This was an explicit attempt at deception. Interestingly, when I was on the Council of Economic Advisors, we tried to stop this. We tried to insist that in their reporting the companies made clear the value of the stock options and the value of what they were transferring to their CEOs.

Not surprisingly, those in the financial markets didn't want transparency or good information; they wanted obfuscation. Effectively, they wanted to continue, to put it one way, to divert resources from their investors to themselves. But it was worse than just a form of theft. It actually led to inefficiency: by focusing on stock market prices, it encouraged distorted information. It was easier for the CEOs to give bad information to get their stock prices up than it was to come up with a good idea, and they became specialists at how to provide distorted information. Of course, without good information, markets cannot work well. In addition, the incentives were designed to encourage excessive risk taking. They got bonuses in good years, but share holders had to bear the cost of the bad years. These kinds of short-sighted incentive systems, with asymmetries between the losses and gains, led to this kind of excessive risk-taking 
in a predictable way and to the gambling that undermined America's financial markets.

In short, there is what can only be described as a huge yawning gap between the private rewards and social returns. While they were supposed to be rewarded for managing risk and allocating capital, they mismanaged risk and misallocated capital. Even they could not appraise the risk of the non-transparent products that they created, and they realized that they didn't know their own balance sheet. As they realized this, they also realized that they didn't know the balance sheet of any firm to whom they might lend, and that is why our financial markets have seized.

At the same time, they failed to create the risk products that people needed to allow them to manage the risks that they faced. This is a really important point, as you hear about the wonders of innovation in America's financial markets. Their innovations were really focused on finding new accounting and new procedures by which they could, first, avoid paying taxes. Those are the innovations that occurred in the seventies. Then in the eighties and early nineties, they took these ideas about how to deceive the Federal government on taxes and figured out how they could simultaneously deceive their investors. It is a hard task because you want to tell the government that your income is very low while telling your investors that your income is very high. That is a conflict, and they figured out how they could do both by keeping complicated books, reporting low income to the tax authorities and high income to the investors. What they finally did is create something that was so complicated that they even deceived themselves, and that is, of course, the problem we face today.

They were innovating in ways that involved tax arbitrage, which is a way of saying 'getting around taxes'; accounting arbitrage, which means 'circumventing the accounting regulations'; and regulatory arbitrage, which means 'getting around the prudential regulations which were intended to provide the stability of our economic and financial system'. While they were engaged in what I would call this destructive innovation, or not constructive innovation, they were not doing the innovation which they should have or would have done had they been social enterprises.

A social enterprise would have said: 'What are the risks that the people that I work for care about? What are the risks that our society cares about?' Take one obvious risk: if you buy a home and take out a mortgage, you want to be able to manage the risk, to stay 
in your home even if interest rates go up or house prices go down, the kinds of economic vicissitudes that all market economies face. However, they didn't innovate in that way, and the result of that is that America is having not only an economic problem today but also a social problem. Three million Americans have already lost their homes, and with their homes, much of their life savings. We expect in the next year another two million Americans will lose their homes. This is a social problem of epic proportions.

Not only did they innovate in ways that were unconstructive, but they have also consistently resisted innovations which would have made our economy work better. For instance, when I was on the Council of Economic Advisors, we noticed that there was no insurance against inflation, which is one of the risks that people worry about, and we proposed coming up with a product, called inflation-indexed bonds, that would help people face inflation. The US Treasury and Wall Street opposed it. At first, I was puzzled, because our analysis said that not only would it make people have a more secure retirement, it would also actually reduce borrowing costs for the government. It was a win-win situation. But Wall Street opposed it because they discovered that if people have these products which protect them against the inflation, they buy them and hold them until their retirement. They don't trade, and Wall Street makes money by transaction costs from these trades. The results of these failures have been disastrous, and now the economy is going through a downturn. I estimate that the gap between what our economy will actually produce and what we could have produced probably will be over two trillion dollars.

It is important to realize that, while the executives of the financial companies have done very well, others are bearing the cost. Not just the home owners who are losing their homes, not just the workers who are losing their jobs, but the taxpayers who have been asked to bail out Fannie Mae, Freddie Mac and Bear Stearns. In a way, now the American taxpayer is the proud owner of the largest bankrupt insurance company, the largest bankrupt financial and mortgage companies, and we are about to become the largest owner of houses in default in the world. Not exactly something, I am sure, that we would want to otherwise have had and which has been done in a way that is a model of bad government.

About a decade ago, in the East Asia crisis, the US Treasury, the IMF, and some of the European countries talked about the lack of transparency in East Asia. That lack of transparency is no comparison to the lack of transparency of the US government and 
what it has done in the last few weeks. We still don't know how much we may have to pay for the Bear Stearns bailout. These bailouts have been totally non-transparent, but what we do know is that the amounts are in the billions or hundreds of billions of dollars. All of this has occurred while the executives have walked away with generous severance packages and while the investors and creditors who enabled all this to happen are being protected. The contrast with what has happened recently and what was said in East Asia a decade ago highlights the hypocrisy of what we are seeing.

So far I've focused on issues of efficiency, but I want to highlight that, in fact, efficiency is not everything in life. In other areas, actually, the standard model works even more poorly.

Markets by themselves often do not produce socially desirable outcomes. The obvious example is the great inequality that is growing in most countries around the world. But another important aspect is the quality of the workplace, which is important because people spend a very large fraction of their lifetime at the workplace, and if the quality of life there is low, it obviously has an adverse effect on the quality of life overall.

\section{Success requires a more balanced economy: a plural economic system}

Success, broadly defined, requires a more balanced economy, a plural economic system with several pillars to it. There must be a traditional private sector of the economy, but the two other pillars have not received the attention which they deserve: the public sector, and the social cooperative economy, including mutual societies and not-for-profits. Let me just comment on the third, which I think has particularly not gotten the attention it deserves in most economic discourse. These are among the most successful parts of the American economy.

Some people looking at the American economy observe that if there is one sector in which we dominate, it is our universities. If you did a list of the ten leading universities in the world, six of them would be in America; the American share of that sector is probably larger than in almost any other industry. Yet, this is a sector which is totally dominated, as I mentioned before, by notfor-profits. In fact, in the list of the top universities, there is not a single one that is for-profit. The history of for-profit universities in 
America has been disastrous. They have occasionally made a profit, but mostly by exploiting the lack of knowledge of the students. They were, for instance, very strong in trying to encourage the government to give student loan programs, but then they would convince students to enroll in their universities and basically not give them a very good education. The students would refuse to repay the loans, and the government would wind up, in effect, picking up the bill. During the Clinton administration, we changed the rules: universities whose students refuse to pay back their loans are a sign that the students felt they didn't get a quality education to get the jobs that were promised, and so we won't lend money to students in these kinds of schools. These schools put an enormous amount of effort into lobbying, because they understood the swindle in which they were engaged. The bottom line is that for-profit universities have been a disaster in America, and the not-for-profit universities, the colleges and the state universities, are really the basis of the successful outcome. These universities are the source of the innovation that underlies much of the strength of the rest of the American economy.

There is also an important role for not-for-profits, cooperatives and mutual societies, in publishing, agriculture, education, health and housing. Just to mention a few: the dominant butter company and the dominant orange juice company are successful cooperatives, and a large fraction of New York housing is cooperatives. That, of course, highlights the need for research to understand the reasons for these successes.

I think the first reason for the success of cooperatives is that democracy, just ordinary democracy, is a value in itself. We all talk about it, but democracy in the workplace is an important element of democracy itself. On the one hand, more socially-oriented enterprises are less inclined to exploit those with whom they interact: their workers, their customers, and their suppliers. This is especially important when competition is limited. Some studies, looking at for instance sugar mills in India, have highlighted that those parts of India where there have been cooperative sugar mills have done much better than those in which there have been for-profit sugar mills. The problems of exploitation are important, not only when competition is limited but also when there are information asymmetries, in which one party can exploit the other, or asymmetries in bargaining power. In market economies these kinds of asymmetries are pervasive. Greater internal democracy can foster not only a better workplace but also a more innovative workplace and a more innovative society. Part of this is based on the notion that with more participation, 
more openness, and more transparent management, there is a better flow of information. Information is necessary for a well-functioning economy and well-functioning enterprises.

It is also the case that the kinds of conflict between workers and management that characterize so many American private sector enterprises are not conducive to a good flow of information, and, therefore, are not conducive to innovation. The standard joke in American enterprises is that the reason we have to pay our CEOs so much money is because it is so painful for them to have to fire so many workers all the time, and the reason they have to fire so many workers is that they have a shortfall of revenue. But the reason they have a shortfall of revenue is because they're paying the CEO so much money. Thus, they have created a vicious circle which doesn't lead to more productivity.

You can understand the flaw in the mindset where you say to a CEO: 'We have to give you 40 million dollars a year, because we understand that if we give you 20 million dollars you will not work hard enough and will only give us half of your attention. That 40 million will give us at least 80 percent of your attention.' Now you ask the question: 'What kind of CEO would only give his full effort if you pay him with strong incentive pay and these mega-mega-bucks?' Do you really want that kind of person running the enterprise? In a sense, what has happened, at least in American enterprises, is that the CEOs have really undermined the compact between workers and management. Rather than having a cooperative arrangement, it is very clear that it is one group trying to extract as much of the value added and rents of the firm as they can, leaving the workers with the minimum amount that is left over.

Systems in which there is more participation, more openness, and more transparent management can also be important in spreading an entrepreneurial culture, where everybody in the firm is part of the decision-making process, which can increase efficiency in the enterprise. But there is another important aspect which has recently received a lot of study, which is job satisfaction. Job satisfaction, as I mentioned before, is an important part of the quality of life. An important study showed that a higher quality workplace, including larger participation in decision-making, leads to greater job satisfaction, even for low-wage jobs. Finally, a higher quality of workplace improves not only the quality of life but also productivity. As I noted, participation leads to better flows of information, and better information leads to better decisions and greater performance from workers. There are also some fundamental psychological aspects of 
this that have been well studied: better performance increases the sense of satisfaction, from what I call intrinsic rewards more than from extrinsic or monitoring rewards. The problem is that the forprofit sector relies almost exclusively on extrinsic rewards. All this says that there is the potential of creating a virtuous circle rather than the vicious circle that I described before.

Now, many of these ideas have played out in the new economy in a very dramatic way. We've seen the success of open source software, and the contrast between the dynamic aspects of this open source software and the profit-maximizing software being produced by some of the monopolists in the USA stands in stark contrast. The notion of cooperative research that is associated with open-source software is now beginning to spread to other areas of innovation, such as green technology: discovering more environmentally-friendly batteries. One of the reasons for the success of the open-source model is that it involves greater participation, leading to better motivation and better outcomes. The consequence of all this is that we need to encourage a variety of alternative forms of economic organization. We (and when I say we I mean the USA and most other Western governments) have focused too long on one particular model, the profit-maximizing firm, and in particular a variant of that model, the unfettered market. We have seen that that model does not work, and it is clear that we need alternative models. We need also to do more to identify the contribution that these alternative forms of organization are making to our society, and when I say that, the contribution is not just a contribution to GDP, but a contribution to satisfaction.

In my introduction, there was a reference to the work that I am doing with President Sarkozy. I am trying to devise alternative measures of GDP and economic performance, as our standard measures are flawed in many ways. They do not reflect sustainability, either in an environmental, social or political sense, and they do not reflect broader sets of values and concerns, including job satisfaction and a sense of well-being. Developing broader measures is one of the key objectives of the commission in which I have been involved.

Let me just conclude by congratulating you on the work that you are doing to try and create a more balanced economy and on the research that will support that greater balance. I described the failures of our current model: we have disproportionately allocated resources, for instance, to housing, beyond people's ability to pay, but we have also disproportionately allocated resources to research in the neo-classical model. In fact, some of this research has been quite bad, 
and in many ways it has contributed to the financial debacle that we are now facing.

I sometimes jokingly say that one of the reasons that we are having this financial crisis is that some of our students at Columbia University listen to only the first third of our lectures. I have lectured about the virtues of diversification, and they ran down and started securitizing based on diversification. But in the second third of the lecture, I tried to explain about correlated risk, systemic risk, and fat-tail probability distributions. That was a little too complicated for these business students, and they didn't want to hear that part of the lecture. The final part of the lecture was about asymmetries of information and that securitization creates new asymmetries of information that will lead to markets working less well. The point is that a little bit of knowledge can be dangerous.

The real problem is that we have not been doing enough research to try and understand alternative models or alternative ways of organizing our society. What we do know at this point is that the model based on market fundamentalism does not work, and that is why it's exactly the right time to begin thinking more about the kinds of models on which you have been working for so long.

THANK YOU 
Copyright of Annals of Public \& Cooperative Economics is the property of Blackwell Publishing Limited and its content may not be copied or emailed to multiple sites or posted to a listserv without the copyright holder's express written permission. However, users may print, download, or email articles for individual use. 